\title{
STUDENTS' DIFFICULTIES IN SOLVING HIGHER-ORDER THINKING SKILLS (HOTS) READING COMPREHENSION SECTION AT SMA 1 TAKENGON
}

\author{
Yunie Amalia Rakhmyta ${ }^{1}$, Alif Maulidiyah ${ }^{2}$ \\ ${ }_{1,2}$ IAIN Takengon, Aceh Tengah, Aceh, Indonesia \\ Email: amalia.nirfan@gmail.com ${ }^{1}$, alifmaulidiyah98@gmail.com ${ }^{2}$
}

\begin{abstract}
This study aims to determine students' difficulties in solving Higher-Order Thinking Skills (HOTS) questions and their dominance due to the reading comprehension section at SMAN 1 Takengon. This study was delivered through a qualitative descriptive research design. Twenty-two students were elected to be research subjects based on purposive sampling. The instruments were documentation and interview. Data analyzed by adopting Miles and Huberman's theory stepped into three-phase; data reduction, data display, and conclusion. As a result, the percentages showed several students' difficulties; first in making inferences about $48 \%$, second, determining the main idea about $26 \%$, third, in detailed information about $18 \%$, last, in understanding vocabulary about $8 \%$. In conclusion, the dominant difficulty is making an inference.
\end{abstract}

Keywords: Students’ Difficulties, HOTS, Reading Comprehension

\begin{abstract}
Abstrak: Penelitian ini dilakukan agar dapat menentukan kesulitan para siswa dalam memecahkan soal berbasis Higher-Order Thinking Skills (HOTS) pada bagian pemahaman bacaan, dan kesulitan mana yang paling mendominasi di SMAN 1 Takengon. Penelitian ini dilakukan dengan desain penelitian kualitatif deskriptif. Dua puluh dua siswa terpilih menjadi subjek penelitian berdasarkan purposive sampling. Instrumen yang digunakan adalah dokumentasi dan wawancara. Analisis data dengan mengadopsi teori Miles, Huberman dan Sadana meliputi reduksi data, penyajian data, dan kesimpulan. Hasilnya, persentase menunjukkan beberapa siswa mengalami kesulitan; pertama dalam membuat kesimpulan sebesar $48 \%$, kedua, dalam menentukan ide pokok sebesar 26\%, ketiga, dalam merinci informasi sebesar 18\%, terakhir dalam memahami kosakata sebesar $8 \%$. Kesimpulannya, kesulitan terbesar adalah membuat kesimpulan.

Kata Kunci: Kesulitan Siswa, HOTS, Pemahaman Bacaan
\end{abstract}

\section{INTRODUCTION}

English is the only foreign language included in the Indonesian K13 Revision curriculum. According to Indonesian Education Ministry regulation, No 22 of 2006 about elementary and middle school standards, aspects when learning English as a foreign language include; reading, listening, writing, and speaking. (Panjaitan, 2010) Mastering English is not as simple as people think; furthermore, consider English a foreign language in Indonesia. The learners probably face many obstacles, especially senior high school students. These students are expected to understand what they have read correctly. It assists them to complete their tasks in reading comprehension tests and open their minds toward the world's occurring issues. According to the K13 Revision Curriculum, the students must understand the social function, textual content structure, and language functions in analyzing various texts in oral and written form (Mariati, 2018).

The students must save the information between what they have read and their knowledge in reading comprehension. These obstacles, especially in solving the reading comprehension section, lead to an unsatisfied final score. In the Indonesian education system, the evaluation phase is divided into six categories, which are $\mathrm{C} 1, \mathrm{C} 2$, and $\mathrm{C} 3$, 
known as Lower-Order Thinking Skills term. Then followed by C4, C5, C6, or often mentioned as Higher-Order Thinking skills (Hoque, 2016). In this research, the term will be mentioned as HOTS.

HOTS was recognizable, to begin with, from the thought of Benjamin S. Blossom amid a book entitled Scientific Categorization of Education Goals: The Classification of directions objectives that categorize changed levels of thought known as Blossom Scientific Classification from exceptionally low to the most noteworthy (Eisner, 2000). The concept of scientific classification for definitive learning objectives is frequently called the ultimate word objective of a learning prepare (Kennedy, Hyland, \& Ryan, 2009). Once a chosen learning handle, students will embrace modern abilities, information, and states of mind. HOTS itself is a component of the mental include domain in Bloom's scientific categorization and points to sharpen mental aptitudes around comprehension. Alice Thomas and Glenda Thorne outline the term HOTS as some way of thinking more than memorizing or retelling one thing that others tell (Thomas \& Thorne, 2010). In keeping with Susan M. Brookhart, HOTS is split into three categories: (a) Higher order thinking as transfer activity, (b) higher-order thinking is crucial thinking, (c) higher-order thinking is problem-solving (Pramesti, Sajidan, \& Dwiastuti, 2018).

Implementing the HOTS standard in English learning at school is very important. HOTS standardized questions have been applied in the standard examination because the indicators used in the questions are analyzed, evaluated, and created. Nowadays, students are expected to know and solve HOTS English questions. Unfortunately, high school teachers are still designing questions based on Lower-Order Thinking Skills (LOTS), which only train students to remember, understand, and apply. In the end, students get used to doing these three aspects in learning. Therefore, students face various difficulties when faced with questions that require more in-depth exploration of ideas, such as the characteristics of HOTS-based questions. That is why the researcher wanted to dig deeper into the students' difficulties in dealing with HOTS questions, especially in the reading comprehension section.

Supported by the observation at SMAN 1 Takengon, several students still do not solve HOTS reading comprehension queries. Analyzing students' HOTS reading comprehension questions is incredibly necessary because it will facilitate academics to determine students' difficulties and as some way for teachers and students to seek out the triggers. This research's points of interest are that instructors or teachers can develop the approach in constructing reading comprehension questions, mainly due to HOTS standardization. The teachers should collect resources and materials to improve the standard of learning English and push students directly and indirectly to progress reading comprehension capacity in English.

\section{LITERATURE REVIEW}

\section{Reading}

The essential ability in achieving good English is reading comprehension. Although it is considered normal, reading requires active cooperation between the reader and the 
meaning of the reading (Arne, 1984). The body's response that functions when reading is the eyes and the brain. The brain works intellectually to capture the substance of reading. In addition, in an article, Ellemand and Oslund stated that reading activities are a collection of practical activities in capturing ideas implied in the arrangement of words (Elleman \& Oslund, 2019). In understanding the reading, the reader at once understands the grammar and the reading message (Fahmi, 2020).

On the other hand, Zadina et al. stated in their book that writers could speak through the words that they compose in writing, and reliable readers must also capture the author's messages appropriately (Zadina, Smilkstein, Daiek, \& Anter, 2014). Thus, there is an invisible two-way communication between the writer and the reader during the reading comprehension. Therefore, reading is considered an active ability because the reader's eyes and brain must be active. When one of them is not active, the reading activity fails.

Furthermore, Grabe and Stoller also assert that reading is a human ability to describe the meaning contained on a written page and then translate it into the form of understanding (Grabe \& Stoller, 2013). Therefore, in reading, a good reader must translate information appropriately. In short, reading is a honed experience, requiring synchronization between the eyes and the brain to encourage understanding of the reading content. Indirectly, the above theories imply that students must be forced to practice reading to have the potential and eligibility to become good readers. If students have practical reading skills, they may have satisfactory results at evaluation. In many ways, students will more easily understand what they are browsing on the internet, scientific reading, and other sources. Therefore, teachers must prepare students to become reliable thinkers because good thinkers start with reliable readers.

\section{Reading Comprehension}

Renandya and other academic experts in reading claimed that human interaction generates and constructs meaning using structured language is called reading comprehension (Renandya, Willy A.Ng \& Chong, 2019). This statement implies that reading comprehension is an activity that goes on without stopping as long as humans live, no matter how short the reading is. On the other hand, Mckee states that reading comprehension is an activity to quickly retrieve data from what is read (Mckee, 2012). The point here is that after understanding the content of the reading, a reader must release the information they get as accurately as possible. This statement is entirely counter to the statements of other theorists that a reasonable reader will undoubtedly be able to bridge the invisible interaction between himself and the author by capturing the author's intentions correctly.

The government continues to promote reading subjects from elementary school to university at the school level. Through reading comprehension of several text genres arranged in the K13 curriculum, students can recognize the language features, text structure, and language choices in these texts (Panjaitan, 2010). Especially for high school students, students must save ideas, convey ideas and share them with friends. 


\section{Higher Order Thinking Skills (HOTS)}

Since they were born, humans have perpetually used their thinking ability to answer the challenge around them. This thinking ability becomes characteristic of social culture. Suppose the students have upper thinking ability, the higher progress of its culture. Generally, flexibility and talent thinking have been tried in family, society, and school. However, some folks aforesaid that faculty becomes the primary influencer in developing thinking ability. There are two classes of thinking ability within the instructional world: Low-Order Thinking Skills and High-Order Thinking Skills (Saido, 2013). LOTS may be a lower thinking ability, whereas HOTS is higher. Nowadays, HOTS has become a wellliked topic as a result of its several advantages and functions in real life.

The HOTS queries are activity instruments to live. It is not solely recalled, restated, or recited (Yuliati \& Lestari, 2018). HOTS question in assessment context measures: transferring knowledge, process and implementing the data, establishing the affiliation from many completely different items of information, victimization the information to unravel the problem, and reviewing the ideas and data critically (Jailani, Sugiman, \& Apino, 2017). HOTS questions are concentrate on metacognitive dimensions. The metacognitive dimension describes connecting the flexibility with several concepts, interpreting, problem-solving, discovering a replacement method, reasoning, and creating the most straightforward decision. In step with Taxonomy Bloom in Krathwol, four levels of ability define as; knowing (C1), understanding (C2), applying (C3), analyzing (C4), evaluating (C5), and making (C6). Generally, HOTS question measures in levels C4, C5, and C6 (Krathwohl, 2002).

The assessment kind principally utilized in HOTS standardized queries is multiple decisions than others. Multiple choices have few surpluses; there are: (a) the original material that has been tested is concerning learning, (b) the solution is straightforward to correct, (c) the assessments are objective (Mitana, 2018).

\section{Students' Difficulties}

Student grades in one or more disciplines will reveal difficulties. As Ying, Siang, and Mohamad stated in their journal, errors made by students in completing assignments and test questions are frequently used to identify students' learning challenges (Ying et al, 2021). It indicates that in school, students' challenges in learning are a problem when it comes to completing tasks and answering assessment questions (Rakhmyta, 2019). The study is an effort to create the relationship between prejudice and reaction. Study means an effort to adapt oneself to the situation around the learners (Biwer et al, 2021), thus statement asserted by Biwer and other academics that can be defined study as an effort done by people to become sensitive people through their environment. When people do this process, indeed, they face some obstacles. In learning, it might call learning difficulties.

As Saladino stated in her article, the developmental learning difficulties include interference of motoric and perception, language difficulties, and communication to adapt social behavior (Saladino, Lin, Zamparelli, \& Verrastro, 2021). At the same time, academic learning disabilities refer to academic failure, including comprehending reading. Learning difficulties are a failure to achieve the goal of learning. When 
appropriate, it can be stated that students with learning disabilities will face obstacles in obtaining learning outcomes (Batubara \& Mahardhika, 2020).

A situation in which students with learning difficulties cannot learn effectively as a result of intervention is caused by both developmental learning disabilities and academic learning disabilities. These obstacles make it difficult for students to grow following their potential.

\section{RESEARCH METHODOLOGY}

This research was delivered with a qualitative descriptive design by collecting ideas, formulating problems, grouping the findings, and describing the results in a narrative following the facts found in the field at the research time. As a type of phenomenology study, the instruments used are documentation and interviews. John and David Cresswell emphasized that qualitative research relies on text and image data, has special steps in data analysis, and the results will refer to various research designs (Creswell, 2018). This research employs a descriptive method. By the descriptive method, the researcher tries to explain the events in the middle of attention while not giving special treatment to those events. Also, the victimization studies the documentation techniques geared toward all research subjects by providing a list guidelines sheet that fills the analyzer. Then, victimization the interview to grasp the student's difficulties typically encountered within the learning process. The first supply is the source that will give valuable data directly (Sugiono, 2015).

A primary source is the twenty-two students from SMAN 1 Takengon, sains class during this research. Supported the definition, the primary source offers distinguished knowledge relating to the research problems. The research results show that in reading comprehension questions, HOTS are operating on. Supported the reason above, knowledge will be taken from the topic in finding students' difficulties in solving the questions. The technique of data collection uses the document and interview-based mostly on purpose. After being collected, the data were analyzed based on Miles and Huberman's theory. There are three steps to investigate the data obtained; data reduction, data display, and conclusion (Miles, Huberman, \& Saldaña, 2013).

\section{FINDINGS AND DISCUSSION Finding}

Based on a series of procedures carried out along the study, the researcher can map students' difficulties in compiling the questions, as can be seen, as follows:

Table 1. Checklist guidelines result

\begin{tabular}{ccccc}
\hline \multirow{2}{*}{ No. } & \multicolumn{2}{c}{ Indicators } & \multicolumn{2}{c}{ Layout } \\
\cline { 3 - 4 } & \multicolumn{1}{c}{ The students cannot remember } & $\sqrt{ }$ & No \\
\hline vocabulary technically. & & & \\
2. & $\begin{array}{l}\text { The students cannot deduce the } \\
\text { information from the questions. }\end{array}$ & $\sqrt{ }$ & \\
\hline
\end{tabular}


3. The students cannot determine the relevant information in questions.

4. The students cannot classify detailed information in questions.

5. The students cannot state the meaning of the terms that represent the questions.

6. The students cannot remember one or more necessary conditions for an object to be expressed in the term that represent the questions.

According to table 1, the researcher classified the difficulties faced by students in solving the HOTS reading comprehension's section as follows:

Table 2. Kinds of difficulties

\begin{tabular}{cc}
\hline No. & Kind of Difficulties \\
\hline 1. & Understanding Vocabulary \\
2. & Determining Main Idea \\
3. & Making Inference \\
4. & Detail Information \\
\hline
\end{tabular}

According to table 2, the difficulty found is the first one that students have difficulty understanding the meaning of some vocabulary or the meaning. It makes students feel challenged to evaluate the correct answer. The second difficulty students face is having problems in concluding the main idea in each paragraph, which is the point of the question. HOTS-type questions require a higher understanding. In contrast, HOTS in linguistics are questions where the answers are not listed on the reading questions openly, but need high understanding, need high analysis, need evaluation height to get the correct answer. The third one is that students have difficulty making inferences in each question. It can be seen that students can not deduce the information from the questions. The last one is that students have difficulty in detailing the information. HOTS questions are the questions that need high analysis. Therefore, students are required to investigate each stimulus given in the questions. This finding has no C6 specification because the document the teacher was given to the researcher is a multiple choice type, so there is no creating aspect. Because it is rarely found in multiple-choice, it is excessively found in essays questions. After the researcher had classified the students' difficulties, the study document also provided and classified the kinds of students' difficulties deeply.

Table 3. Students' difficulties classification

\begin{tabular}{cccccc}
\hline No. & Initials & $\begin{array}{c}\text { Understanding } \\
\text { Vocabulary }\end{array}$ & $\begin{array}{c}\text { Making } \\
\text { Inference }\end{array}$ & $\begin{array}{c}\text { Detail } \\
\text { Information }\end{array}$ & $\begin{array}{c}\text { Determining } \\
\text { Main Idea }\end{array}$ \\
\hline 1 & AIW & 0 & 2 & 3 & 2 \\
\hline
\end{tabular}


Jurnal As-Salam Vol. 5 No. 2 Juli - Desember 2021: 153 - 163

Yunie Amalia Rakhmyta, Alif Maulidiyah

\begin{tabular}{cccccc}
\hline 2 & IFP & 1 & 9 & 3 & 4 \\
3 & ARA & 1 & 3 & 3 & 4 \\
4 & MRI & 2 & 3 & 3 & 3 \\
5 & UAL & 2 & 11 & 4 & 4 \\
6 & FSY & 2 & 9 & 4 & 5 \\
7 & FSH & 2 & 9 & 3 & 6 \\
8 & EDA & 2 & 8 & 3 & 4 \\
9 & NQA & 1 & 10 & 2 & 6 \\
10 & FRA & 2 & 9 & 2 & 4 \\
11 & AMA & 1 & 8 & 3 & 4 \\
12 & IAP & 2 & 9 & 2 & 4 \\
13 & FHA & 1 & 10 & 3 & 5 \\
14 & AZP & 1 & 7 & 1 & 4 \\
15 & ITA & 1 & 9 & 3 & 4 \\
16 & RMA & 2 & 6 & 4 & 3 \\
17 & AKH & 0 & 9 & 3 & 2 \\
18 & TTM & 0 & 4 & 3 & 6 \\
19 & SUN & 1 & 9 & 1 & 5 \\
20 & AHA & 1 & 10 & 1 & 5 \\
21 & ISB & 1 & 8 & 3 & \\
22 & DFK & 1 & 8 & 4 & \\
Total of Each & $\mathbf{2 7}$ & $\mathbf{1 7 0}$ & $\mathbf{6 1}$ & \\
Difficulties & & & & \\
Total of All & & & 349 & & \\
Difficulties & & & & 5 \\
\hline
\end{tabular}

Table 3 showed 349 difficulties from the student's result sheet. Those 349 difficulties were classified into this, as follows as:

a. Students difficulties in understanding vocabulary were 27

b. Students difficulties in making inferences were 170

c. Students difficulties in determining the main idea were 61

d. Students difficulties in detail information were 91

From the interview session, the teacher of SMAN 1 Takengon claimed that there are two significant difficulties faced by the students in solving Higher-Order Thinking Skills question. First of all, the students got low scores in solving the questions because the application of HOTS in the learning process did not fully align with the HOTS criteria. Second, students are confused in solving the questions if all the questions in each exam are categorized as HOTS. Students will be too lazy to answer it and tend to be careless about answering the questions. The result of this interview was that students felt difficulty understanding new vocabulary and were confused about how to conclude the text.

\section{Discussion}

This study found two main things until it came to the discussion section. Let through to the figure below. 


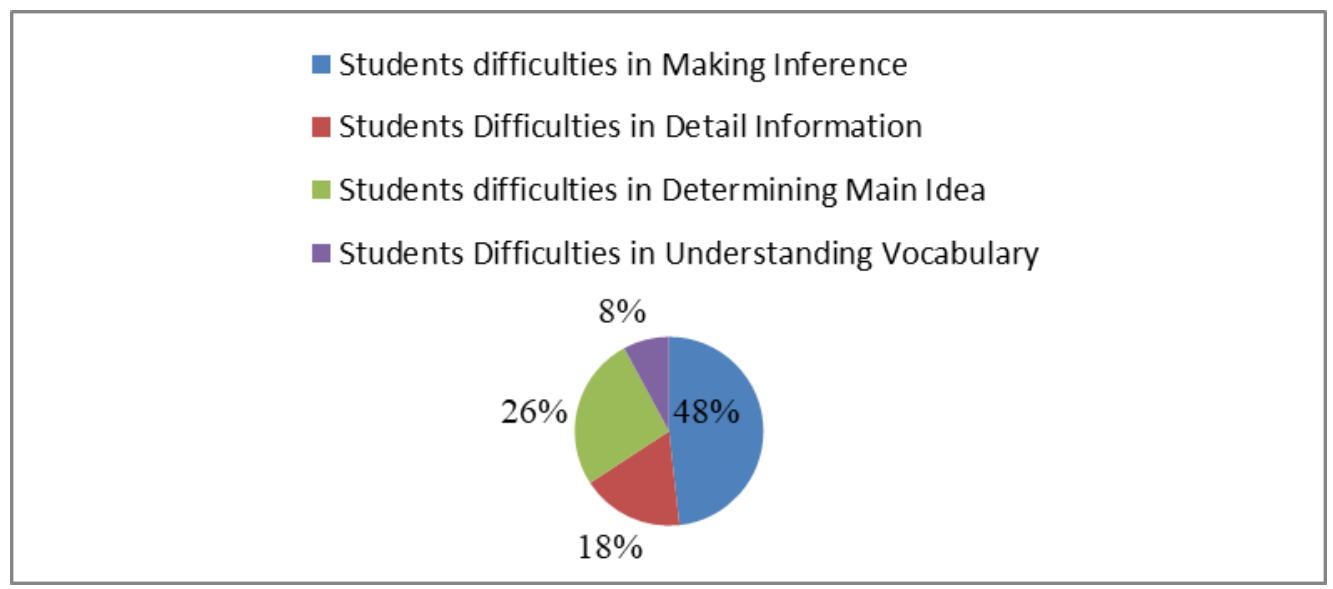

Figure 1. Most dominant of difficulties in solving hots reading comprehension's section

Based on figure 1, students' difficulties in making inferences are $48 \%$, students' difficulties in determining the main idea reached $26 \%$, in detail information section are $18 \%$, and difficulties in understanding vocabulary are $8 \%$. It can be concluded that making an inference is the most significant difficulty. As it is known, HOTS has C4, C5, and C6, where each aspect has its criteria. The aspects of $\mathrm{C} 4$ include analyzing, comparing, investigating, criticizing, testing; C5 includes evaluating, assessing, opposing, deciding, choosing, supporting; C6 includes constructing, designing, creating, developing, writing, formulating. This extended analysis found that the dominant student difficulty is C5, namely evaluating, where one of the aspects in C5 is evaluating and determining.

The researcher found that there are $8 \%$ students' difficulties in the understanding vocabulary of the question items, $48 \%$ students' difficulties in making inferences of the question items, $18 \%$ of student's difficulties in detail information of the question items, and $26 \%$ of students' difficulties in determining the main idea of the question items.

The researcher concluded from students' scores classification that in SMAN 1 Takengon, the students faced difficulty solving Higher-Order Thinking Skills (HOTS), especially in the reading comprehension section. In this research, the researcher tried to identify the kinds of students' difficulties in solving HOTS reading comprehension questions precisely the mistake they had made on their test. The researcher also thoroughly identified the students' dominant difficulties in solving HOTS reading comprehension questions. The result of the study is the document result and verified by interviews from the teacher and students.

From table 3 students' difficulties in solving the HOTS reading comprehension's section, there are limitation as follow:

1. The errors experienced by students in understanding new vocabulary make it challenging to understand the contents of the text if there is vocabulary that they do not know. It means that vocabulary needs to do more additional exercises in English to achieve mastery. Especially in daily conversation.

2. Several students have prepared to study hard but still feel difficulty solving it.

3. Several students cannot decide where the main idea is. 
4. Several students cannot specify the detailed data and conclude even the students knew several vocabularies.

In the interview session, the teacher confirmed that their student's difficulty raised in solving HOTS was caused by several factors those are as follows:

1. Inputting of HOTS questions on the exam is not given $100 \%$ but only $40 \%$

2. Teachers are afraid to give a lot of HOTS-type questions because they are worried that students will not be able to do well. It causes students not to be appropriately trained in working on HOTS questions.

Based on the study, the document and interview results found several students difficulties in solving HOTS reading comprehension questions: understanding, vocabulary, determining the main idea, making inferences, and detail information. The researcher tried to agglomerate the aspects of HOTS with the result finding of this research; those are as follow:

1. The difficulties in understanding vocabulary belong to the understanding aspect $(\mathrm{C} 2)$ because to understand the vocabulary, need to explain more about that lexicon, these difficulties found as many as $8 \%$.

2. The difficulties in determining the main idea and detailed information belong to analyzing aspect $(\mathrm{C} 4)$ because to get the primary idea needs more investigation activity to investigate the text found as $26 \%$.

3. To see the detailed information (C4), the students have to specify the detail of the information. This difficulty found as many as $18 \%$.

4. The difficulties in making inference belong to Evaluating aspect (C5) because in order to make inference need more deciding and evaluating activity; these difficulties found as many as $48 \%$.

5. The Creation aspect (C6) was not found or $0 \%$ because the teacher's document was given to the researcher is multiple choice.

\section{CONCLUSIONS}

The first research problem is finding out the students' difficulties in solving HOTS reading comprehension questions. Those are students' difficulties understanding vocabulary, making inferences, detailed information, and determining the main idea. The second problem is to figure out the students' primary obstacles. There are students difficulties in the evaluation aspect (C5) where students feel difficulty making an inference. By this result, the students' difficulties in solving the HOTS reading comprehension section at SMAN 1 Takengon are common. Several things must be addressed to improve the quality of learning and teaching. The primary students have to familiarize students with HOTS-based questions. In addition, the way teachers teach must also continue to be developed to adapt to the growth of the times and the latest methods.

\section{REFERENCES}

Batubara, M. H., \& Mahardhika, M. G. S. (2020). An Analysis On Students' Difficulties In Changing Active To Passive Voice. Jurnal As-Salam, 4(1 SE-Articles), 61-78. https://doi.org/10.37249/as-salam.v4i1.175 
Biwer F, Wiradhany W, oude Egbrink M, H. H., \& Wasenitz S, J. W. and de B. A. (2021). Changes and Adaptations: How University Students Self-Regulate Their Online Learning During the COVID-19 Pandemic. Frontiers in Psychology, 12(April), 1-12.

https://doi.org/10.3389/fpsyg.2021.642593

Bruce Arne, S. (1984). Teaching reading skills in a foreign language. System, 12(2), 188190.

https://doi.org/10.1016/0346-251x(84)90031-9

Creswell, W. John \& Creswell, J. D. (2018). Research Design: Qualitative, Quantitative and Mixed Methods Approaches. Journal of Chemical Information and Modeling (Vol. 53).

Eisner, E. W. (2000). Benjamin Bloom. Prospects, 30(3), 387-395. https://doi.org/10.1007/bf02754061

Elleman, A. M., \& Oslund, E. L. (2019). Reading Comprehension Research: Implications for Practice and Policy.

Retrieved from https://doi.org/10.1177/2372732218816339

Fahmi, I. N. (2020). Higher Order Thinking Skill Questions in Reading Comprehension Exercise of "When English Rings A Bell" Textbook. Retain, 8(4), 187-193. https://jurnalmahasiswa.unesa.ac.id/index.php/43/article/download/35789/31832

Grabe, W., \& Stoller, F. L. (2013). Teaching and researching reading, second edition. Teaching and Researching Reading, Second Edition.

Retrieved from https://doi.org/10.4324/9781315833743

Gulistan Mohammed Saido. (2013). Higher Order Thinking Skills Among Secondary School Students in Science Learning. The Malaysian Online Journal of Educational Science, 3(3), 13-20. http://files.eric.ed.gov/fulltext/EJ1085914.pdf

Hoque, M. E. (2016). Three Domains of Learning: Cognitive, Affective and Psychomotor. The Journal of EFL Education and Research, 2(February), 25205897.

Retrieved from www.edrc-jefler.org

Jailani, J., Sugiman, S., \& Apino, E. (2017). Implementing the problem-based learning in order to improve the students' HOTS and characters. Jurnal Riset Pendidikan Matematika, 4(2), 247-259.

https://doi.org/10.21831/jrpm.v4i2.17674

Kennedy, D., Hyland, Á., \& Ryan, N. (2009). Learning outcomes and competencies. Using Learning Outcomes: Best of the Bologna Handbook, 33, 59-76.

https://www.semanticscholar.org/paper/Learning-Outcomes-and-Competences-

Kennedy-Hyland/423a3e8656c0990f516ca78ace21ec79eacf8440

Krathwohl, D. R. (2002). A Revision Of Bloom's Taxonomy Of Educational Objectives. Theory into Practice, 41(4), 302.

http://www.citeulike.org/user/mapto/article/961573\%5Cnhttp://www.mendeley.co $\mathrm{m} /$ research/a-taxonomy-for-learning-teaching-and-assessing-a-revision-of-bloomstaxonomy-of-educational-objectives-abridged-edition1/\%5Cnhttp://www.amazon.ca/exec/obidos/redirect?

Mariati, M. (2018). Penerapan Alat Evaluasi Pembelajaran Bertingkat Berdasarkan Taksonomi Bloom Dalam Meningkatkan Kemampuan Berfikir Mahasiswa. Liabilities (Jurnal Pendidikan Akuntansi), 1(2), 95-111. https://doi.org/10.30596/liabilities.v1i2.2328

Mckee, S. (2012). Reading Comprehension, What We Know: A Review of Research 
Jurnal As-Salam Vol. 5 No. 2 Juli - Desember 2021: 153 - 163

Yunie Amalia Rakhmyta, Alif Maulidiyah

1995 to 2011. Language Testing in Asia, 2(1), 45-58.

https://doi.org/10.1186/2229-0443-2-1-45

Miles, M., Huberman, M., \& Saldaña, J. (2013). Qualitative Data Analysis: A Methods Sourcebook. USA: Sage.

Mitana, J. (2018). Assessment of higher order thinking skills: A case of Uganda Primary Leaving Examinations. African Educational Research Journal, 6(4), 240-249. https://doi.org/10.30918/aerj.64.18.083

Panjaitan, M. O. (2010). Penilaian Mata Pelajaran Bahasa Inggris. Jurnal Pendidikan Dan Kebudayaan, 16(3), 311-324. https://doi.org/10.24832/jpnk.v16i3.464

Pramesti, B., Sajidan, S., \& Dwiastuti, S. (2018). Stimulating Higher-Order Thinking skills (HOTs) with the Module on Metabolism Topic at the Senior High School in Surakarta, 262(Ictte), 315-318. https://doi.org/10.2991/ictte-18.2018.58

Rakhmyta, Y. A. (2019). Students' Difficulties In Listening And Understanding Speech. Jurnal As-Salam, 3(1 SE-Articles), 13-22. https://doi.org/10.37249/as-salam.v3i1.116

Renandya, Willy A.Ng, Q. R., \& Chong, M. Y. C. (2019). Extensive reading: Theory, research and implementation. Teflin Journal, 30(2), 171-186. https://doi.org/10.15639/teflinjournal.v30i2/171-186

Saladino, V., Lin, H., Zamparelli, E., \& Verrastro, V. (2021). Neuroscience, Empathy, and Violent Crime in an Incarcerated Population: A Narrative Review. Frontiers in Psychology, 12(July), 1-14. https://doi.org/10.3389/fpsyg.2021.694212

Sugiono, P. (2015). Metode Penelitian Kombinasi (Mix Metods). Bandung: Alfabeta.

Thomas, A., \& Thorne, G. (2010). How to Increase Higher Order Thinking. Retrieved from https://www.semanticscholar.org/paper/How-to-Increase-Higher-OrderThinking-Thomas-Thorne/e1ac293c0dd2aeb6f1d61ed17fde3547cd483bcc

Yong Hua Ying, Winson Eng Wei Siang, M. M. (2021). The Challenges of Learning English Skills and the Integration of Social Media and Video Conferencing Tools to Help ESL Learners Coping with the Challenges during COVID-19 Pandemic: A Literature Review. Creative Education, 12(07), 1503-1516. https://doi.org/10.4236/ce.2021.127115

Yuliati, S. R., \& Lestari, I. (2018). Higher-Order Thinking Skills (Hots) Analysis of Students in Solving Hots Question in Higher Education. Perspektif Ilmu Pendidikan, 32(2), 181-188. https://doi.org/10.21009/pip.322.10

Zadina, J. N., Smilkstein, R., Daiek, D. B., \& Anter, N. M. (2014). College Reading: The Science and Strategies of Expert Readers. Retrieved from https://books.google.com.pk/books?id=GdYWAAAAQBAJ 